\title{
Žieda Tamašauskaitè
}

Vytautas Magnus University, Lithuania

\section{GOTHIC WORD ORDER PATTERNS AS ATTESTED IN THE GOTHIC GOSPEL OF LUKE}

Summary. Gothic is the oldest attested Germanic language that possesses features similar to Proto-Germanic i.e., the parent language of all contemporary Germanic languages. The grammar of the Gothic language not only comprises distinctive features of native origin, but also contains peculiarities inherited from Proto-Germanic as well as traces of non-Germanic impacts. The peculiar nature of Gothic grammar reveals itself in Gothic syntax, and notably in the order of words. The article aims at defining word order patterns in The Gothic Gospel of Luke, Chapter 4 with special reference to word order in a phrase and sentence. Firstly, word order in Gothic phrases is considered, and the most recurrent word order patterns in noun and verb phrases found in Luke 4 are defined. Secondly, word order patterns and peculiar features of simple sentences and principal clauses are discussed. Finally, the article comments upon the choice of word order in those types of subordinate clauses that are represented in the chapter of Luke selected for the analysis as well as compares word order in principal and subordinate clauses. All comments on Gothic word order and syntactic features are provided with examples from Luke 4. The analysis of Gothic word order patterns is performed by fusing two research methods i.e., descriptive and analytic. Being the only attested East Germanic language, Gothic has a great linguistic value. Therefore, the study of Gothic word order and syntax is of great significance for the reconstruction of Proto-Germanic, for understanding word order patterns in other Germanic languages as well as for identifying common Germanic features.

Keywords: Gothic, The Gothic Gospel of Luke, noun phrases, principal clauses, simple sentences, subordinate clauses, syntax, verb phrases, word order, word order patterns, complex sentences.

\section{Introduction}

Gothic is the oldest attested Germanic language and the only East Germanic language that has a sizeable corpus. Antedating other Germanic tongues by about four centuries, Gothic possesses many archaic features of Proto-Germanic, native peculiarities as well as traces of non-Germanic origins. The peculiar nature of Gothic reveals itself in word-stock, phonology, morphology and, most notably, syntax. Consequently, one of the possible ways to comprehend peculiarities of Gothic is to analyse its syntax with special reference to word order patterns.

The object of research is word order in phrases and sentences of The Gothic Gospel of Luke, Chapter 4. The aim of the article is to define common Gothic word order patterns by analyzing phrases and sentences of Luke 4. In order to achieve the aim the following objectives are set: to define the word order in noun and verb phrases; 
to identify word order patterns in simple sentences; to trace word order patterns in subordinate clauses; and to comment upon the choice of word order and identify word order patterns in complex sentences of The Gothic Gospel of Luke, Chapter 4.

The analysis of Gothic word order patterns is performed by applying descriptive and analytic methods. The descriptive aspect is concerned with supplying a general description of predominant Gothic word order patterns. The analytic aspect, in turn, is concerned with providing a detailed analysis of nominal and verbal groups, clauses and sentences from the selected chapter of The Gothic Bible, thereby exemplifying Gothic word order patterns and validating the descriptive aspect of the analysis. In the article, all Gothic phrases and sentences that serve as examples are taken from The Gothic Gospel of Luke, Chapter 4 as it appears in the digital library Project Wulfila. ${ }^{51}$ In order to convey grammatical aspects of the phrases and sentences, word-for-word translations ${ }^{52}$ from Gothic to English are provided by the author of the article.

The incentive to carry out a study on Gothic word order was given by the realization of the great linguistic value that the Gothic language manifests and the fact that, despite this value, Gothic has slipped past the attention of linguists for too many years. However, detailed analyses of Gothic grammar are important for the reconstruction of Proto-Germanic, the parental language of the group of Germanic languages. Moreover, the knowledge of Gothic may contribute to understanding the development of contemporary Germanic languages as well as to defining common Germanic features.

\section{The Gothic tribe(s) and the Gothic Bible}

The historical background of the Germanic tribe known as the Goths touches upon the development of their language and forms its characteristic features hardly observed in other Germanic tongues. The Goths were the first Germanic tribe to migrate from their home in Götland, Southern Scandinavia, and depart from other Germanic tribes. Having crossed the Baltic Sea, they settled near the Vistula in BC 100 . However, the aspiration to move forward was soon to come, and the Goths left for the shores of the Black Sea. As Prokosh (1939, pp. 28-30) notes, it was near the Danube where the history of the tribe took a significant turn: not only did the Goths split into the Visigoths 'the good Goths' and the Ostrogoths 'the brilliant Goths', but they also came into contact with Christianity, and became the first Germanic tribe to be Christianized.

Conversion to Christianity conditioned the need to translate The Bible from Greek into Gothic. The majority of biblical translations are thought to have been made by Ulfilas, a Cappadocian descent born around AD 311 and consecrated the bishop of the Visigoths in AD 336 (Durant, 1992, p. 46). After becoming a bishop, Ulfilas started to spread Aryanism among the Goths and provided them with translations of the Scriptures. However, the persecution and rages of the Huns pushed the Visigoths out of their kingdom to Moesia, Italy and other parts of southwest Europe. While in the Roman Empire, the Goths joined the Roman military forces and undertook

51 Project Wulfila (http://www.wulfila.be/) is a digital library hosted by the University of Antwerp. The project focuses on Gothic and other old Germanic languages and provides linguistically annotated editions of old Germanic texts.

52 For literary translations of The Gothic Gospel of Luke, Chapter 4 refer to Project Wulfila (http://www.wulfila.be/gothic/browse/ text/?book=3\&chapter=4). 
an insensible assimilation with other nations. The immigration to the Roman Empire was fatal to the Goths: not only did they lose their individuality, but they also abandoned their language (Wolfram, 1988, p. 14). Despite all this, in the $X V I^{\text {th }}$ century vestiges of Gothic were transcribed in the Crimea, a place where a small part of the great tribe survived longest (Baugh \& Cable, 2002, p. 32).

The corpus of the Gothic heritage is comprised of five codices i.e., Codex Argenterus, Codex Carolinus, Codices Ambrosianus, Codex Turinensis and Codex Gissensis, the first being the most solemn of them. In Codex Argenterus ${ }^{53}$ one may find 187 folios (out of 330) with the inscriptions of the four Gospels made by the Ostrogoths around AD 500. The Gothic Bible has a great linguistic value as it is the oldest sizeable text written in a Germanic language and the only written testimony of the extinct Gothic language.

\section{Principal features of Gothic}

The seclusion of the Goths from their kinsmen as early as AD 100 and the migration to the shores of the Black Sea and the southwest Europe, alongside with contacts to speakers of other nations, made the language of the Goths develop in a way different from the languages of the North and West Germanic tribes. Therefore, in the Gothic language not only common Germanic features, but also elements inherited from languages of non-Germanic peoples may be attested.

Heterogeneous nature of Gothic can be detected almost everywhere in the language. Consider the Gothic alphabet: the alphabet, which dates back to AD 350, was created on the basis of the Greek alphabet and enriched with several Latin letters and two runic symbols. Despite the fact that in the Gothic alphabet the sequence of letters corresponded to that of Greek, the phonetic values showed some differences (Safra, 1998, p. 382). Moreover, the alphabet comprised a specific Gothic letter $h$ $\left[h^{w}\right]$ and was abundant in digraphs. Thereby, "the Gothic alphabet shows the relation of the Goths with the Greeks and Romans as well as with the Germanic people" (Fairbanks, 1940, p. 324).

The Gothic vowel system had five long vowels /i:, e:, $a:, o:, u: /$, three short vowels $/ i, a, u /$ and three diphthongs /iu, ai, au/, the latter two of which used to represent the sounds $[\varepsilon]$ and [o] respectively when followed by the consonants $/ r, h, h /$; this process is known as The Gothic Breaking. As regards the Gothic consonant system, it is considered to have been rather phonemic except for the consonants $/ \mathrm{b} /, / \mathrm{b} /, / \mathrm{d} /$ and $/ g /$, which used to be voiced in intervocalic position (Lehmann, 2005, pp. 23-25). It is important to note that due to the early seclusion of the speakers of Gothic from the speakers of other Germanic tongues and the early extinction of the language, Gothic did not undergo certain morphological and phonological changes, for example i-umlaut ${ }^{54}$, that other Germanic languages did.

53 The University of Uppsala provides a facsimile edition of Codex Argenterus online (http://app.ub.uu.se/arv/codex/faksimiledition/ contents.html).

54 i-umlaut or i-mutation is a sound change concerned with the fronting of back vowels in a syllable. In many old Germanic languages, back vowels of stressed syllables developed a fronted allophone when preceded by an unstressed syllable with /i/ (van Kemenade, 2005, p. 114). 
In its morphology, Gothic did not differ much from other old Germanic languages. Gothic was a synthetic language: nouns and adjective were subject to inflections; nominal parts of speech had three numbers (singular, dual and plural) and four cases; verbs indicated tense, mood, voice, person and number; etc. Other parallels with the languages of the group include reduplicated verbs, the division of verbs into strong, weak and preterite-presents verbs, the heavy use of ablaut ${ }^{55}$, the development of prepositive article, the use of anaphoric pronoun and many more (Prokosh, 1939, p. 30). In contrast to morphology, which was purely Germanic, Gothic syntax is believed to have been affected by Greek syntax. Nevertheless, many syntactic features were Germanic or purely Gothic, such as the position of attributes, predicative attributes or optative and medio-passive forms. In addition to this, Gothic syntax exhibited a significant shift from Object-Verb (OV) syntax into Verb-Object (VO) syntax.

\section{Word order in Gothic}

\section{Word order in noun and verb phrases}

Gothic word order is thought to have been relatively free and mostly dependent on stylistic and logical factors. Despite this, in the sentences of The Gothic Gospel of Luke, Chapter 4 certain word order patterns are attested more frequently than other patterns. Written records provide support for the assumption that in Gothic noun phrases were structured as much with reference to stylistics and logic as with reference to morphological aspects. In the noun phrases of The Gothic Gospel of Luke, Chapter 4, attributes that agree with the head noun in all grammatical categories (number, case and gender) either follow or precede the noun, as e.g., allans piudinassuns 'all the kingdoms', unhrainjam ahmam 'unclean spirits', ahmins weihis 'spirit holly', in dagam jainaim 'in days those', in andwairpja meinamma 'in personality mine', in ausam izwaraim 'in ears your', etc. However, noun phrases with attributes in post-position to nouns outnumber those with a reverse word order.

In case attributes did not agree with the head noun in all grammatical categories or the agreement was not full, they followed the noun they modified. The lack of grammatical agreement between the constituents is usually detected in those noun phrases that comprise a noun in the genitive case functioning as an attribute e.g., piudangardi gudis 'kingdom of God', in Saraipta Seidonais 'in a city of Sidon', stika melis 'moment of time', siponjos is 'followers his', in daga sabbato 'on the day of Sabbath', etc. In addition to this, it might be found in noun phrases with certain cardinal number for Gothic cardinal numbers from twenty to one hundred did not agree in case with the noun they modified (Wright, 1954, pp. 116-117). Regardless of Wright's observations, in the noun phrases of Luke 4, all numbers follow the noun they modify e.g., dage fidwor tiguns 'for days forty', menops saihs 'months six' and jeram prim 'years three'. Taking everything into consideration, in the noun phrases of The Gothic Gospel of Luke, Chapter 4 two word order patterns can be singled out i.e., noun-attribute and attribute-noun, the former being characteristic to OV syntax, whereas the latter being characteristic to VO syntax. Due to the fact that the

55 Ablaut is the gradation of vowels in stem and suffix within series of related vowels e.g., steigan, staig, stigum, stigans. Although most clearly seen in strong verbs, ablaut could occur in almost any part of speech (Wright, 1954, pp. 45-47). 
incidence of nouns following attributes is less noticeable than the incidence of the noun-attribute pattern, the pattern characteristic to OV syntax may be considered as the predominant word order pattern in Gothic noun phrases.

Lehmann (2005, pp. 34-35) notices rather a conspicuous and archaic Gothic word order pattern. He claims that in Gothic positive sentences with a predicate adjective the auxiliary is followed the adjective. The analysis of verb phrases of Luke 4 not only proves the pattern to have existed, but also manifests it to have been a common word order pattern in Gothic verb phrases e.g., sunaus sijais 'son is', gamelid ist 'written is', qipan ist 'said is', atgiban ist 'delivered is', gredags warp 'hungry was', andanems ist 'accepted is', etc. Another peculiarity of Gothic verb phrases to be considered is the heavy use of present participles to modify the main verb. When used attributively, the so-called predicative attributes could be either preposed to the principal verb, as e.g., in andhafjands qap 'answering said' or pairhleipands pairh midjans ins iddja 'passing through the midst went', or postposed to the principal verb, as e.g., in andhof Iesus wipra ina qipands 'answered Jesus to him saying', ufhropida, qipands 'cried, saying' and rodidedun du sis misso qipandans 'spoke among themselves, saying'. Lehmann (2005, p. 35) claims this feature to be characteristic to OV languages, thereby suggesting OV as the native Gothic word order. Гухман (1958, p. 222), in turn, considers this to have been employed to show and specify a feature of a process expressed by the predicate, and notices that in case the predicative attribute gained independence from the predicate, it could became the nucleus of the clause.

As regards yet another constituent of verb phrases i.e., the object, it could either follow or precede the verb. Direct objects were likely to follow the verb, as e.g., in wairpip pein 'will be yours' and atstandands ufar ija 'stood over her', where the pronouns in the accusative pein 'yours' and ija 'her' follow the verbs wairpip 'will be' and atstandands 'stood' respectively. However, verb phrases that have a reverse word order e.g., the phrase ana handum puk ufhaband 'with his hands you hold', with the verb ufhaband 'hold' that precedes the pronoun in the accusative puk 'you', are also recurrent in The Gothic Gospel of Luke, Chapter 4.

Referring to Schendl (2001, pp. 42-43), it is worth adding that unlike VO languages, where verbs precede objects, auxiliaries precede main verbs and adjectives precede the nouns they modify, OV languages demonstrate the reverse order. Gothic seems to have had many characteristic of an OV language, such as, e.g., objects preposed to verbs, auxiliaries following adjectives and attributes following the noun. However, noun and verb phrases also showed features of VO languages, such as objects postposed to verbs or attributes preceding the noun. Having encompassed characteristics of two different types of languages, Gothic cannot be easily assigned either to VO or OV languages, at least as far as word order patterns in noun and verb phrases are concerned.

\section{Word order patterns in simple sentences and principal clauses}

In Gothic, the structure of simple sentences was similar to that of other old Germanic languages, i.e., a simple sentence was made of a verb $(\mathrm{V})$, which was the core of the sentence, and could include a subject (S), one or more objects (O), adverbial modifiers (A), attributes modifying nouns or verbs (att) and, very commonly, an introductory 
conjunction (cj). However, due to the nature of Gothic morphology and foreign influences on the language, simple sentences had their own distinctive features, which are seldom found in other tongues. To begin with, one of the peculiar features of Gothic simple sentences was the presence of a formal marker i.e., a personal verb, which made it possible to miss out the subject. In Grammar of the Gothic Language, Wright (1954, pp. 188-189) claims this pattern to have been influenced by Greek syntax. Consider Table 1 which contains sentences (principal clauses) taken from The Gothic Gospel of Luke, Chapter 4. Despite the fact that the clauses lack the subject i.e., they have neither a noun nor a pronoun in the nominative, they contain personal verbs, namely gatauh 'took' and faifalp 'closed', implying that the actor is a third person.

Table 1

\section{Word order patterns in simple sentences and principal clauses with an implied subject}

\begin{tabular}{|l|l|l|l|}
\hline A & V & O & A \\
\hline Paproh & gatauh & ina & in Iairusalem \\
\hline From there & (he) took & him & to Jerusalem \\
\hline
\end{tabular}

\begin{tabular}{|l|l|l|}
\hline cj & V & 0 \\
\hline jah & Faifalp & pos bokos \\
\hline And & (he) closed & those books \\
\hline
\end{tabular}

Simple sentences and principal clauses of The Gothic Gospel of Luke, Chapter 4 provide support for the assumption that in Gothic, not only a noun or pronoun in the nominative case, but also a substantive adjective, infinitives or participles could function as the subject. According to Lehmann (2005, p. 35), the use of the infinitive as the subject indicates that the infinitive originally was nothing but a verbal noun. As regards the position of the subject in the sentence, it could either stand in preposition or postposition to the verb, as well as it could either follow or precede the object.

In the first sentence given in Table 2, the subject (S) Jesus 'Jesus' stands in between the object and the verb; in the second sentence, the subject Jesus 'Jesus' stands sentence finally; whereas in the final sentence, the subject Jesus 'Jesus' follows the verb, but preposes the object. It should be remarked that in The Gothic Gospel of Luke, Chapter 4, the incidence of the patterns exemplified i.e., OSV, VOS and VSO, is rather equal. This allows presuming that in Gothic simple sentences and principal clauses the subject did not have its fixed position and the choice of word order pattern was determined by stylistic and logical factors as well as by word order of the source language text, which in the case of The Gothic Bible was Greek.

Taking into consideration the predicate, it is important to make a distinction between simple and compound predicates. In order to express simple predicates, a personal form of verbs was generally used, whereas compound predicates were expressed by modal verbs duginnan 'to begin' or haban 'to have', an infinitive or a link-verb and a predicative. Under the influence of Greek texts, Gothic sentences sometimes contained a compound predicate without a link-verb. Purely Gothic compound substantival 
predicates, in turn, consisted of a link-verb (wisan 'to be', wairpan 'to become' or some other verb) combined with a noun, adjective or participle.

Table 2

Position of the subject in simple sentences and principal clauses

\begin{tabular}{|l|l|l|l|l|}
\hline cj & att & O & S & V \\
\hline jah & andhafjands & imma & Iesus & qab \\
\hline And & answering & to him & Jesus & said \\
\hline
\end{tabular}

\begin{tabular}{|l|l|l|l|l|}
\hline $\mathrm{cj}$ & att & $\mathrm{V}$ & $\mathrm{O}$ & $\mathrm{S}$ \\
\hline jah & andhafjands & qap & imma & Iesus \\
\hline And & answering & said & to him & Jesus \\
\hline
\end{tabular}

\begin{tabular}{|l|l|l|l|l|}
\hline $\mathrm{cj}$ & $\mathrm{V}$ & $\mathrm{S}$ & 0 & att \\
\hline jah & andhof & Iesus & wibra ina & qibands \\
\hline And & answered & Jesus & to him & saying \\
\hline
\end{tabular}

In Gothic sentences, the object was commonly expressed by a noun or pronoun in the genitive, dative or accusative. In some other cases, prepositional constructions could function of objects. Objects were divided into direct and indirect objects, as well as objects in the genitive, objects in the dative and objects in the accusative. The case of the noun used as an object usually depended on the verb, since certain verbs governed certain cases. Nevertheless, with some verbs the accusative and dative were used either synonymously or with a slight difference in meaning. As compared with nouns in the genitive case, which were either direct or indirect objects, nouns in the accusative case always served as direct object (Wright, 1954, pp. 182-184).

\section{Position of the object in simple sentences and principal clauses}

\begin{tabular}{|l|l|l|l|l|l|}
\hline cj & V & O & S & att & A \\
\hline jah & gawandida & sik & Iesus & in mahtai ahmins & in Galeilaian \\
\hline And & took & himself & Jesus & in the power of the Spirit & to Galilee \\
\hline
\end{tabular}

\begin{tabular}{|l|l|l|l|}
\hline cj & V & O & A \\
\hline jah & gasatida & ina & ana giblin alhs \\
\hline and & put & him & on the gable of the temple \\
\hline
\end{tabular}

\begin{tabular}{|l|l|l|}
\hline O & V & O \\
\hline pus & giba & pata waldufni pize allata jah wulpu ize \\
\hline To you & I will give & that authority of these all and fame their \\
\hline
\end{tabular}


The position of verbs and objects in simple sentences and principal clauses of The Gothic Gospel of Luke, Chapter 4 suggests Gothic to have had a relatively free word order. In the Gospel, both verbs and objects take either the first, second or third position and, thereby, either precede or follow one another. Consider the sentences in Table 3 with reference to word order. In the first sentence, the pronoun in the accusative sik 'himself' follows the verb gawandida 'took', and in the second sentence, the pronoun in the accusative ina 'him' follows the verb gasatida 'put' precedes; the verb preposed to the object implies VO patterning. In the third sentence, the noun in the dative pus 'to you' precedes the verb giba 'I will give', whereas the noun in the accusative waldufni 'authority' and wulpu 'fame' follow the verb, implying the residues of OV pattern.

Taking everything into consideration, Gothic simple sentences and principal clauses can be said to manifest two different patterns: OV and VO. Nonetheless, higher incidence of VO pattern gives support for the assumption that Gothic, as contemporary Icelandic, Dutch, Frisian and German had an object shift (Zwart, 1997, p. 252), and OV patterns occasionally attested in simple sentences were but residues of earlier OV syntax (Lehmann, 2005, pp. 34-35). Yet another residue of OV syntax can be detected in simple direct questions, usually formed by attaching the enclitic particle $-u$ to the first word of a question, e.g. Niu sa ist sunus Iosefis 'Not he is the son of Joseph?'. The position of the particle after the first word may be regarded not only as a relict of OV syntax, but also as a peculiarity of the Gothic language that could not have derived either from Greek or Latin (Fuss, pp. 2003, 203).

In addition to the principal parts of a sentence, adverbial modifiers of time, place, cause, purpose and manner deserve mentioning. Adverbial modifiers are found to have commonly been expressed by an adverb, a noun in the genitive, dative or accusative and prepositions. As regards their position in simple sentences and principal clauses, they were most likely to open sentences and clauses or stand sentence/clause finally. Consider the clauses and sentences given in Table 4 with a special reference to the position of adverbial modifiers.

Table 4

Position of adverbial modifiers in simple sentences and principal clauses

\begin{tabular}{|l|l|l|l|}
\hline V & 0 & 0 & A \\
\hline Ataugida & imma & allans piudinassuns pis midjungardis & in stika melis \\
\hline Showed & him & all kingdoms of this world & in a moment \\
\hline
\end{tabular}

\begin{tabular}{|l|l|l|}
\hline A & V & S \\
\hline in pizai swnagogein & was & manna \\
\hline in this synagogue & was & a man \\
\hline
\end{tabular}

\begin{tabular}{|l|l|l|l|}
\hline A & V & O & A \\
\hline Paproh & gatauh & ina & in Iairusalem \\
\hline From there & took & him & to Jerusalem \\
\hline
\end{tabular}


As the examples from The Gothic Gospel of Luke, Chapter 4 show, Gothic adverbial modifiers either open sentences and clauses, as in pizai swnagogein in this synagogue' and paproh 'from there' or stand sentence/clause finally, as in stika melis 'in a moment' and in Iairusalem 'to Jerusalem', without any pronounced difference in meaning. However, it should not be forgotten that due to the nature of Gothic morphology, which supported a relatively free word order, adverbial modifiers were free to occur in any position in a sentence so as to convey a certain meaning or aspect.

\section{Word order patterns in complex sentences and subordinate clauses}

A greater part of The Gothic Bible is written in complex sentences i.e., sentences which consists of a principal clause and one or more subordinate clauses, joined to the principal clause by relative, demonstrative or interrogative pronouns, conjunctions, adverbs or particles suffixed by -ei (Lehmann, 2005, pp. 27, 36). Among the subordinate clauses, nearly all types of clauses are found in the Gospel, although the incidence of subject, object, conditional and time clauses is greater than the incidence of other types of clauses. The heavy use of complex sentences is as likely to have been conditioned by the nature of the text analyzed i.e., a religious text, and the syntax of its source language i.e., Greek, as by the nature of Gothic syntax.

In The Gothic Gospel of Luke, Chapter 4, principal clauses both follow and precede subordinate clauses, suggesting the order of clauses within a Gothic complex sentence to have been variable. Consider the following complex sentences (Table 5) in terms of the order of clauses within sentences.

Table 5

\section{Order of clauses in complex sentences}

\begin{tabular}{|l|l|}
\hline conditional clause & principle clause \\
\hline pu nu jabai inweitis mik in andwairpja meinamma, & wairpip pein all \\
\hline You now if worship me in my personality, & will be everything yours \\
\hline
\end{tabular}

\begin{tabular}{|l|l|}
\hline principle clause & reason clause \\
\hline jah paim anparaim baurgimwailamerjan ik skal bi piudangardja gudis & unte dupe mik insandida \\
\hline And to the other cities preach I shall about the kingdom of God & because for that (I) am sent \\
\hline
\end{tabular}

In the first sentence presented in Table 5, the principal clause wairpip pein all 'will be everything yours' follows the conditional clause pu nu jabai inweitis mik in andwairpja meinamma 'you now if worship me in my personality'. In the second sentence, however, the principal clause precedes the clause of reason unte dupe mik insandida 'because for that (I) am sent'. Despite the fact that in Gothic subordinate clauses could either precede or follow principal clauses, certain subordinate clauses were more likely to yield the first place in the sentence to principal clauses. Therefore, it is crucial to discuss the most recurrent types of subordinate clauses in more detail.

The first to be considered are subject and object clauses, as they are some of the commonest subordinate clauses in Luke 4. In Gothic, the marker of an object clause was 
either the conjunction patei 'that', which was also used to introduce a subject clause, or one of the following conjunctions: pei 'that'; ei 'that', or haiwa 'how' (Гухман, 1958, p. 234). The mood of the verb depended on the predicate of the principal clause; thus, if the principal clause contained the verbs hugjan 'to think' or munan 'to consider', the object clause was more likely to possess a verb in the subjunctive mood, whereas the verbs witan 'to know' and qiban 'to say' in the principal clause conditioned the use of the indicative mood in the object clause. In subject clauses, a verb in the indicative or subjunctive mood was used. Consider Table 6 which contains complex sentences taken from The Gothic Gospel of Luke, Chapter 4.

Table 6

\section{Position of subject and object clauses in complex sentences and word order in subject and object clauses}

\begin{tabular}{|c|c|c|c|c|c|c|c|c|}
\hline \multicolumn{4}{|c|}{ principle clause } & \multicolumn{5}{c|}{ object clause } \\
\hline $\mathrm{V}$ & $\mathrm{A}$ & att & $\mathrm{O}$ & $\mathrm{cj}$ & $\mathrm{A}$ & $\mathrm{V}$ & $\mathrm{S}$ & $\mathrm{A}$ \\
\hline dugann & pan & rodjan & du im & patei & himma daga & usfullnodedun & mela & po in ausam izwaraim \\
\hline Begun & than & say & to & that & this day & become fulfilled & scripture & in ears their \\
\hline
\end{tabular}

\begin{tabular}{|c|c|c|c|c|c|}
\hline \multicolumn{2}{|c|}{ principle clause } & \multicolumn{4}{c|}{ subject clause } \\
\hline Att & $\mathrm{V}$ & $\mathrm{cj}$ & $\mathrm{O}$ & $\mathrm{V}$ & 0 \\
\hline Gamelid & ist & auk patei & aggilum seinaim & anabiudip & bi puk \\
\hline Written & is & for that & to angels his & (he) should give charge & over you \\
\hline
\end{tabular}

As the examples from the Gospel show, in Gothic complex sentences, object and subject clauses tended to follow the principal clause thereby retaining characteristics of VO syntax. As regards word order patterns within the two types of subordinate clauses, elements of both VO patterning and OV patterning can be attested. Thus, in subject and object clauses the verb could precede the subject and follow or precede objects; the subject could either be implicit or explicit; and adverbial modifiers could stand either at the beginning or the end of a subordinate clause.

Table 7

\section{Position of conditional clauses in complex sentences and word order in conditional clauses}

\begin{tabular}{|l|l|l|l|l|l|l|}
\hline \multicolumn{4}{|l|}{ conditional clause } & \multicolumn{4}{l|}{ pinciple clause } \\
\hline cj & att & V & att & V & 0 & 0 \\
\hline jabai & sunaus & sijais & gudis & qip & pamma staina, & ei wairpai hlaibs \\
\hline If & son & (you) are & of God & order & this stone, & to become bread \\
\hline
\end{tabular}

\begin{tabular}{|l|l|l|l|l|l|l|}
\hline \multicolumn{2}{|l|}{ conditional clause } & \multicolumn{3}{l|}{ principle clause } \\
\hline cj & att & V & att & V & 0 & A \\
\hline jabai & sunaus & sijais & gudis & wairp & puk & papro dalap \\
\hline If & son & (you) are & of God & step & yourself & from there down \\
\hline
\end{tabular}




\section{Position of adverbial clauses in complex sentences} and word order in adverbial clauses

\begin{tabular}{|l|l|l|l|l|}
\hline \multicolumn{4}{|l|}{ principle clause } & clause of place \\
\hline cj & V & A & cj & V \\
\hline jah & am & in Nazaraib, & parei & was fodips \\
\hline And & (he) came & to Nazareth, & where & (he) had been brought up \\
\hline
\end{tabular}

\begin{tabular}{|l|l|l|l|l|l|l|l|l|}
\hline \multicolumn{4}{|l|}{ clause of time } & \multicolumn{3}{|l|}{ principle clause } \\
\hline S & $\mathrm{cj}$ & att & V & A & cj & V & S & 0 \\
\hline Swaihro & pan & pis Seimonis & was anahabaida & brinnon mikilai & jah & bedun & ina & bi po \\
\hline Mother-in-law & when & of Simon & was taken & with a fewer great & and & sought & he & for her \\
\hline
\end{tabular}

No less recurrent are conditional clauses, which in Gothic used to be of two types: real condition clauses and unreal condition clauses. It is important to note that both types of conditional clauses were joined by the conjunctions jabai 'if' and nibai/niba 'unless'. However, only real condition clauses possessed a verb in the indicative mood, whereas clauses of unreal condition had a verb in the subjunctive mood (Гухман, 1958, pp. 238-240). As in the examples given in Table 7, in many more complex sentences of the Gospel analyzed, conditional clauses precede principal clauses. As for word order patterns within conditional clauses, patterns applicable to principal clauses and simple sentences ${ }^{56}$ are applicable to conditional clauses.

Finally, adverbial clauses of time and place and attributive clauses are to be discussed. In Gothic clauses of time used to be introduced by the conjunctions pan 'when' and bipe 'when', which governed the indicative mood, and the conjunction faurpizei 'before that', which governed the subjunctive mood. The adverbial clauses of place, in turn, were introduced by the conjunction pei 'that' and adverbs parei/ padei 'where' and included a verb in the indicative mood. Gothic adverbial clauses of time and place and attributive clauses made use of both OV and VO pattern, although it was also rather common for conjunctions to follow the subject or the verb. In the first sentence presented in Table 8, the conjunction parei 'where' is followed by the verb was fodips 'brought up', whereas in the second clause, the first comes the subject swaihro 'mother-in-law'. In addition to exemplifying word order patterns within adverbial clauses, the examples in Table 8 demonstrate that the position of adverbial clauses in a sentence was variable: clauses of time and place could both follow and precede the principal clause.

Taking into consideration word order patterns in subordinate clauses, it is worth to point out that they did not differ from those of simple sentences or principal clauses ${ }^{57}$ and reflected characteristics of both OV and VO syntax. In Gothic, word order was rarely employed to indicate relations between words in a sentence and was relatively free (Lehmann, 2005, pp. 27, 36). Therefore, the position of clauses within a complex sentence was not fixed either although certain tendencies were more recurrent than the other.

56 see Word order patterns in simple sentences and principal clauses.

57 see Word order patterns in simple sentences and subordinate causes. 


\section{Conclusions}

Word order patterns attested in The Gothic Gospel of Luke, Chapter 4 suggest Gothic to have retained many patterns of OV syntax. As in OV languages, in Gothic noun phrases attributes were likely to follow the nouns they modified, whereas in Gothic verb phrases predicate attributes could precede auxiliary verbs and participles modifying verbs could follow the verbs. Besides, in Gothic simple sentences, as well as in principal and subordinate clauses, objects could be placed at the beginning of a sentence, and thereby, precede the verb and the subject.

In addition to patterns of OV syntax, Gothic phrases, clauses and sentences are found to have exhibited a completely reverse word order. In spite of the fact that the incidence of attributes in postposition to nouns seems to have been greater, attributes could also precede the nouns they modified. In simple sentences and principal clauses, in turn, objects were as likely to follow the verb as to precede it and the subject could either precede or follow the verb or be left out of the sentence. Besides, the position of principal clauses within a complex sentence also varied and the principal clause either followed or preceded subordinate clauses.

All the facts considered suggest that Gothic, which is claimed to have been shifting from OV to VO syntax, had characteristics of both OV and VO patterning. Although in some cases patterns of OV syntax are much more common than those of VO syntax, in the other cases namely features of $\mathrm{VO}$ are detected as characteristic. Therefore, in Gothic neither of the patterning can easily be defined as more occasional than the other.

\section{References}

Baugh, A. C., \& Cable, T. (2002). A History of the English Language. London: Routledge.

Durant, W. (1992). The Age of Faith. The Story of Civilization: 4. Norwalk: The Easton Press.

Fairbanks, S. (1940). On Writing and Printing Gothic. Speculum, 15, 313-327.

Fuss, E. (2003). On the Historical Core of V2 in Germanic. Nordic Journal of Linguistics, 26, 195-231.

Safra, E. J. (ed.) (1998). The New Encyclopædia Britannica. Volume 5. Chicago: Encyclopædia Britannica Inc.

Lehmann, W. P. (2005). Gothic and the Reconstruction of Proto-Germanic. E. König \& J. van der Auwera (eds.) The Germanic Languages (19-38). London: Routledge.

Гухман, М. М. (1958). Готский Язык. Москва: Высшая Школа.

Prokosch, E. (1939). A Comparative Germanic Grammar. Baltimore: Woverly Press.

Project Wulfila (2004). The Gothic Bible. Luke chapter 4. Retrieved from

http://www.wulfila.be/gothic/browse/text/?book=3\&chapter=4.

Schendl, H. (2001). Historical Linguistics. Oxford: Oxford University Press.

van Kemenade, H. (2005). Old and Middle English. E. König \& J. van der Auwera (eds.) The Germanic Languages (110-141). London: Routledge.

Wright, J. (1954). Grammar of the Gothic Language. Oxford: Clarendon Press.

Wolfram, H. (1988). The History of the Goths. Los Angeles: University of California Press.

Zwart, J. W. (1997). The Germanic SOV languages and the Universal Base Hypothesis. L. Haegeman (ed.) The New Comparative Syntax (246-267). London: Longman. 


\section{Žieda Tamašauskaitè}

Vytauto Didžiojo universitetas, Lietuva; z.tamasauskaite@uki.vdu.It

\section{GOTU KALBOS ŽODŽIU TVARKOS MODELIAI REMIANTIS GOTIŠKĄJA EVANGELIJA PAGAL LUKA}

Santrauka. Gotu kalba yra išnykusi germanu kalba, kuria kalbejo rytu germanu gentis gotai. Gotu kalba yra ne tik vienintelè rytu germanu kalba, kurios rašytiniu šaltiniu išliko iki mūsu dienu, bet ir kalba, kuria užrašyti seniausi germanu genčiu rašto paminklai. Būdama viena seniausiai susiformavusiu germanu kalbu, gotu kalba turi daug germanu prokalbės bruožu. Be to, šios kalbos gramatikoje aptinkama ne tik savitu, tik germanu prokalbei ar gotu kalbai būdingu savybiu, bet ir elementu, atkeliavusiu i šia kalba iš senuju Europos kalbu. Gotu kalbos unikalumas ir daugialypiškumas puikiai atsiskleidžia sintaksejje, ypač sakiniu ir fraziu žodžiu tvarkoje. Sio straipsnio tikslas yra apibūdinti žodžiu tvarkos modelius gotu kalboje, remiantis modeliais, aptinkamais gotiškosios Evangelijos pagal Luka IV skyriuje. Straipsnyje nagrinéjama žodžiu tvarka veiksnio ir tarinio grupèse bei nustatomi šiu grupiu išskirtiniai sintaksiniai bruožai. Siekiant apibūdinti sakinio žodžiu tvarkos modelius, analizuojami vientisiniai ir pagrindiniai pasirinkto Evangelijos skyriaus sakiniai, demesi skiriant ir labiausiai paplitusiems, ir rečiau aptinkamiems žodžiu tvarkos modeliams bei sintaksiniams bruožams. Straipsnyje taip pat pateikiami sudètiniu ir šalutiniu gotu kalbos sakiniu žodžiu tvarkos modeliai bei lyginama šalutiniu ir pagrindiniu sakiniu žodžiu tvarka. Visi analizuojami žodžiu tvarkos modeliai ir sintaksès bruožai iliustruojami pavyzdžiais iš gotiškosios Evangelijos pagal Luka IV skyriaus. Zodžiu tvarkos modeliai analizuojami jungiant du tyrimu metodus: aprašomaji ir analitini. Lingvistiniu požiūriu itin vertinga gotu kalba svarbu tyrinèti ir studijuoti. Išsamesnis gotu kalbos sintaksès pažinimas gali padèti ne tik rekonstruojant germanu prokalbę, bet ir nustatant senuju germanu kalbu sintaksės bruožus, ieškant bendru germanišku gramatikos bruožu ar analizuojant germanu kalbu sintaksès raida.

Pagrindinès sąvokos: gotu kalba, gotiškoji Evangelija pagal Luka, pagrindiniai sakiniai, sintaksè, šalutiniai sakiniai, tarinio ir veiksnio grupès, vientisiniai sakiniai, žodžiu tvarkos modeliai, sudètiniai sakiniai. 